\title{
THE PETS:Game Introduction of Pets in Two Languages
}

\author{
Wahyu Febriyanto \\ Game Technology Department, Faculty of Computer Science \\ Soegijapranata Catholic University \\ J1.Pawiytan Luhur IV, Semarang, Indonesia \\ wahdoer@gmail.com \\ T. Brenda Chandrawati .ST., MT \\ Game Technology Department, Faculty of Computer Science \\ Soegijapranata Catholic University \\ J1.Pawiytan Luhur IV, Semarang, Indonesia \\ brenda@unika.ac.id \\ Erdhi Widyarto N .ST., MT \\ Game Technology Department, Faculty of Computer Science \\ Soegijapranata Catholic University \\ J1.Pawiytan Luhur IV, Semarang, Indonesia \\ erdhi@unika.ac.id
}

\begin{abstract}
Introducing environment to children is important. What includes in this environment is the life of living beings such as humans, animals, and plants. The role of parents is needed in introducing the living creatures. One of the living creatures that are endeared by children is animals, especially the pets. Therefore, making educational game "The Pets" will be interesting. With the game "The Pets" it is expected to help parents to teach the children about pets based on place of living and food.This paper describes how to design and create introducing pet game based on the type of food and its habitat in two different languages . "The Pets" has the Android platform with a minimum API Level 14 is created using the game engine Construct2. Using two dimensional model and image with interesting coloring for children, and using the application CorelDrawX4. From theresults of the survey, it is found that "The Pets" can provide new knowledge and can assist children in learning about pets based on place of living and food. Children who previously could not mention pets in English, after playing "The Pets" can name them in English.
\end{abstract}

Keywords-Game, Education, the Pets, Pets, Interactive Learning

\section{INTRODUCTION}

Learning is a proc ess or e ffort made by someone to obtain a new change in behavior as the result of previous experiences in daily interaction[1]. Learning process is needed to stimulate $t$ he $g$ rowth of children, in $t$ his period $t$ he $\mathrm{c}$ hild $\mathrm{i}$ s e asy $\mathrm{t}$ o unde rstand instructional material provided.

In addition to learning that can stimulate the $g$ rowth of e arly c hildhood, other processes that can introduce children to the surrounding e nvironment is through the process of $\mathrm{pl}$ aying. $\mathrm{P}$ laying is i mportant to do in early childhood be cause at that ag e children are not familiar w ith anything but playing. According to Piaget, playing is an activity done voluntarily and self-motivated and can cause $\mathrm{p}$ leasure $\mathrm{t} o$ those $\mathrm{w}$ ho play it[2].

Besides, playing al so has be nefits $\mathrm{s}$ uch as increasing $\mathrm{t}$ he abi lity of ki nesthetic and children's motor de velopment of $t$ he ri ght brain that af fect em otional intelligence and children's creativity, and c an develop children's ability to solve a problem[3].

There is another opinion on the definition of playing, often called the game. According 
to Mintorogo, game is an activity that has a provision that aims to have fun and also can be us ed a $\mathrm{s}$ children's 1 earning $\mathrm{m}$ edia[4]. Through gaming, it can increase the interest of young $\mathrm{c}$ hildren $\mathrm{t}$ o 1 earn. In a ddition, children can play through interactive games, and children can a lso get $t$ he s cience of learning pasted on game.

However, learning methods are applied to the formal schools using traditional learning ones. That makes 1 earning $\mathrm{m}$ ethods a $\mathrm{s}$ a learning cen ter teachers and students as learning objects This methodemphasizes the mastery of 1 earning $m$ aterials and text oriented subject matter [5].

To s upport c hildren's understanding of the learning material, the authors will create educational $\mathrm{g}$ ames as a s uggestion to s tudy and play to introduce children to pet, type of food a nd a lso a ha bitat of the p et and its translation in English instead of $t$ raditional methods us ing materials s uch as textbooks. This $g$ ame i s i ntended for y oung chi ldren between the ages of 3-6 years.

\section{LITERATUR REVIEW}

\subsection{Sense of play}

According to Piaget, playing is a hum an activity that is done repeatedly intended as a pleasure[2]. Besides playing as a m eans of achieving g ood pro gress de velopmentally kinesthetic, motoric, right brain development and emotional intelligence $\mathrm{i} n$ expr essing their creativity[3].

Meanwhile, according to Andang Ismail playing is an activity $\mathrm{f}$ or $\mathrm{pl}$ easure $\mathrm{w}$ ithout finding out who won and lost. This activity is done voluntarily without duress[6].

\subsection{The function of playing for children}

Playingfor children functionsas a $\mathrm{m}$ eans of $g$ etting $t$ he chi ld that should a lso be interspersed with learning provide a stimulus to the ch ild. one interesting $\mathrm{m}$ ethod of learning is with games[2].In the game there is an element of pleasure.

\subsection{Stages of play}

According to Piaget 's theory in[7], there are 4 phases in playing, namely:

\section{a. Sensory Motor Play (including age}

3/4 - 6 months)

In this stage children use nerves, smooth muscles, and their feelings.

\section{b. Symbolic / Make Believe Play (2 - 7 years)}

In this $\mathrm{s}$ tage chi ldren play real $\mathrm{g}$ ames using media in their daily lives

\section{c. Social Play Games With Rules (8 - 11 years)}

Children's games are conducted in groups and are limited by rules that are still modest

\section{d. Games With Rules \& Sports (11 year more)}

These ar e playground activities and exercise ac companied by $\mathrm{r}$ ules $\mathrm{t}$ hat $\mathrm{h}$ ave been authorized or simplified.

\subsection{Understanding of learning}

There is some sense of learning according to the exp ert. According t o[1]learning i s a process or effort made by someone to obtain a new cha nge i $n$ behavior a $s$ a result of previous experience in daily life interaction.

Meanwhile, according $\mathrm{t} \quad \mathrm{O}$ Hintzman[2]learning the changes that occur within the o rganism can be humans or animals ba sed on the exp erience $g$ ained. Thus, it can influence the be havior of bot $h$ organisms.

\subsection{Learning through games}

Play the game now has become a lifestyle and fa miliar $w$ ith $t$ he $g$ eneration of young people, especially those in urban areas.

Now chi ldren aged under f ive ar e al ready familiar with the various gaming devices and games in playstation and computers [8].

Childhood is a period where they can be specifically receptive to the stimuli given to him. This pe riod is v ery sensitive chi ld if given the stimulus, they will eas ily capt ure the intent of the stimulus s o that they can remember it till adulthood. Through g ames children can be stimulated easily because children can easily cat ch a sensitive i ssue [9].

\subsection{Understanding of games}

According to [4]game is an activity that has a provision that aims for funand can also be used as a children's learning media. Based on the above statement it can be concluded 
that game $\mathrm{c}$ an be us ed for $\mathrm{c}$ hild e ducation facilities.

\subsection{Stages tomake game}

According $t \mathrm{o}[8]$, in making the $\mathrm{g}$ ame there are five aspects to be considered:

- Determining genre of game

Choose one of $t$ he genres $t$ hat will be addressed. Genre specifies the targeted age i $\mathrm{n} \mathrm{m}$ aking $\mathrm{g}$ ames, for example, for kids thegenre used is usually casual

- Determining tool use

Tool selection is important. Tool maker facilitates in making the game, for e xample if $y$ ou $\mathrm{w}$ ant 3 dimensional $\mathrm{t}$ ools, uni ty is $\mathrm{u}$ sually used.

- Determining gameplay

The flow of the game affects the player'sinterest. Gameplay enables players to play the game

- Determining graphic

Selection of $g$ aming $g$ raphics adapt the genre of the game, whether it's a cartoon or realist

- Determining audio

Audio affects the a tmosphere of games played.

\subsection{Understanding bilingual}

According Bloomfield bilingual is those who $\mathrm{c}$ an $\mathrm{m}$ aster and us e $\mathrm{t}$ wo or $\mathrm{m}$ ore different 1 anguages in pronunciation a nd vocabulary [10].

This study us es two different 1 anguages namely English and Indonesian, in terms of voice, text and ot hers. So it is expected thatchildren can understand the game created in two different languages.

\subsection{Benefits of being bilingual}

It will be easier to communicate because it controls structure of two or more different languages because people do not frequently adapt people using a different language [10].

According to Matlin, a bilingual child is more flexible in the sense that they can be adapt to use different languages and are more likely creative [10] .

\section{RESEARCH METHODOLOGY}

\subsection{PlanningSystem}

Game development method is a way to be used in game de velopment $r$ esearch whichwas c onducted on the $t$ ools and techniques to achieve the purpos es of research on game de velopment. In $t$ he development of $\mathrm{t}$ his $\mathrm{g}$ ame de velopment model, re search methods are used to develop or com plete $t$ he $s$ tudies $t$ hat ha ve been done to get more detailed research and innovation[11].

First literature study i s done to s harpen the issues and theories that are applied in this study. One s tudy is m ade as a comparison between the exi sting games and the development. Similar games, namely game " Belajar Mengenal Binatang " was made by Bamboo Media [12]. This game introduced animals like as birds, polar animals,fish, and wild animals.In addition there ar e o ther studies relating to the introduction of animal puzzle game animals [11].

\subsection{Game design}

This game application is $\mathrm{d}$ esigned and manufactured for $\mathrm{t}$ he A ndroid-based application that can be pl ayed via a smartphone or $t$ ablet that ha $\mathrm{s} A$ ndroid operating $\mathrm{s}$ ystem. I $\mathrm{n}$ de signing a $\mathrm{nd}$ manufacturing game called " The Pets", the game eng ine as $\mathrm{w}$ ell as i mage pr ocessing applications are us ed in orde $\mathrm{r} t \mathrm{o}$ get programming and graphics that s upport the designing and $\mathrm{m}$ anufacturing $\mathrm{t}$ he game [8].Game engine is a software used to design and create a $g$ ame. Game eng ine ha s a function as a means of rendering $2 \mathrm{D}$ and $3 \mathrm{D}$ graphics, ph ysics e ngine, a udio c ontrol, scripting, animation, game, AI ( Artificial Intelligence), networking, streaming and setting chart[13].

\section{Gameplay "The Pets"}

Besides cont aining 1 earning materials, "The Pets" is also an educational gameso that children do not get bored to play this game.

At $t$ he be ginning of menu there i s an options:Indonesian 1 anguage a nd E nglish, then just $g$ o to the main $m$ enu. If the Indonesianis choosen, it will s peak 
Indonesian with all-inclusive $\mathrm{v}$ oice $\mathrm{f}$ or an explanation, and vice $\mathrm{v}$ ersa $\mathrm{i} f \mathrm{~s}$ electing English. In the main menu there are menus based on the habitat of the animals. There are three habitats taken from pets, namely land, air, water. There ar e addi tional $\mathrm{m}$ enu a s a navigation menu in-game sound a nd language, setting menu.

\section{GUI (Graphic User Interface) Design "The Pets"}

In game development, layout of the title, menu, and background need to be considered in orde $r$ to a llow a us er or us ers to understand the fl ow of $t$ he $g$ ame which is played[14]. "The Pets" ar e designed usingGUI that i ncludes na vigation by 1 and, air, water and setting. From the main menu of habitat selection of pet is the scene menu for land, air, and water that contains a menu to learn and play so that children get learning from the introduction of animal and can play mini $g$ ame. Figure 3.2 is a 1 ayout de sign scene of inland navigation.

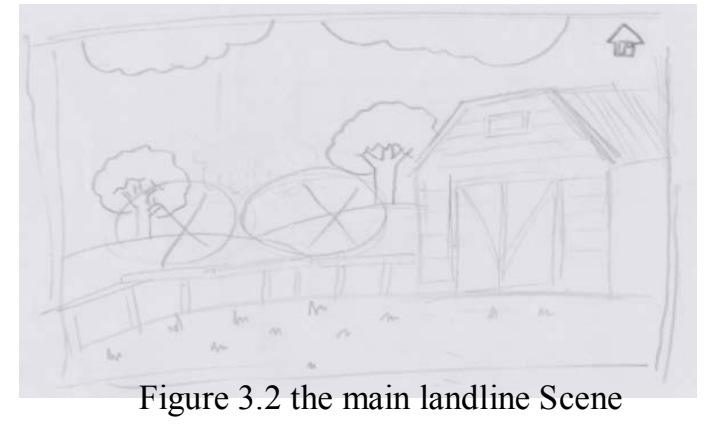

Then, in each habitat there is a GUI design for 1 earning, w hich i $\mathrm{st}$ he form of the introduction of $p$ ets a ccording $t$ ot heir habitat. There is recognition in the form of pictures of a nimals, a nimal $\mathrm{s}$ ounds, $\mathrm{s}$ ound accompaniment, and $\mathrm{t}$ he pet food. $\mathrm{T}$ he design of $t$ he menu scene recognition as an example is shown in the figure 3.3.

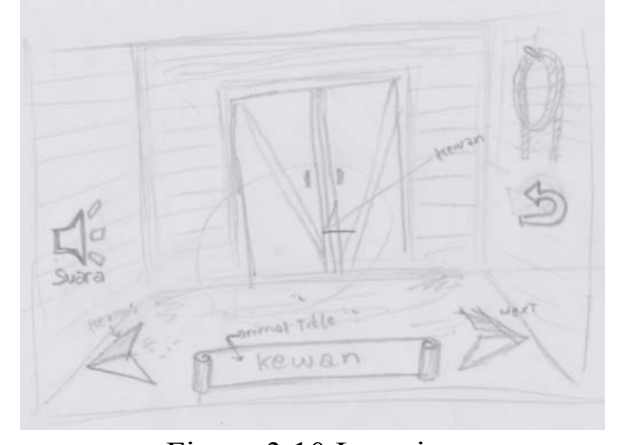

Figure 3.10 Learning scene

\section{RESULTS AND DISCUSSION}

\subsection{Making games}

For the chosen game engine in the making "The $\mathrm{P}$ ets", Cons truct2 chosen is image processing a pplication Core 1Draw X4 . Cosntruct 2 was selected because it is light in terms of usage and can also be used in multiplatforms. Coreldraw $\mathrm{x} 4$ is selected for each because it $i$ s on ef $t$ he app lications processing vector images whichare stable in generating drawings and coloring suitable for game "The Pets".

\subsection{Display game}

Display game or game interface plays a $n$ important $r$ ole $\mathrm{i} n$ a $\mathrm{g}$ ame. The $\mathrm{d}$ isplay of pictures arearranged on a regular layout that makes g ame be comes i nteresting. In Construct 2 an image is called layout. Design view is created in such a way that user does not e xperience prob lems i $\mathrm{n}$ operating the game "The Pets". Here is a de scription of layout view of th game:

\section{Splash screenmenu}

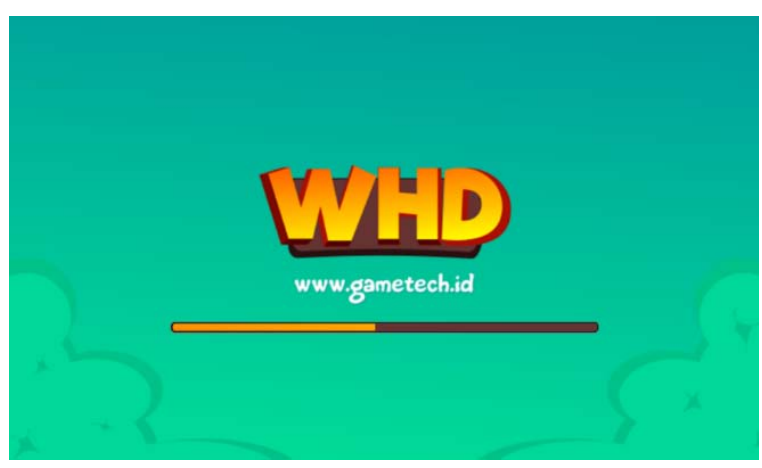

Figure 4.1 SplashscreenDisplay

Figure 4.1 i s a di splay of splash screen menu of "The P ets". Splash screen menu here is used to inform the beginning and is used to preload the asset picture and sound in the game. Loading ba $\mathrm{r}$ is used as indicator lights i n preload image and sound, w hen loading bar is full, it will appear next scene.

\section{Main menu}

Main $\mathrm{m}$ enu c ontains $4 \mathrm{~m}$ enu opt ions, namely land, air, water and setting.Figure 4.2 is a 1 ayout view main menu. Main menu is the most important menu in the game where it controls the layout to the other menus. 


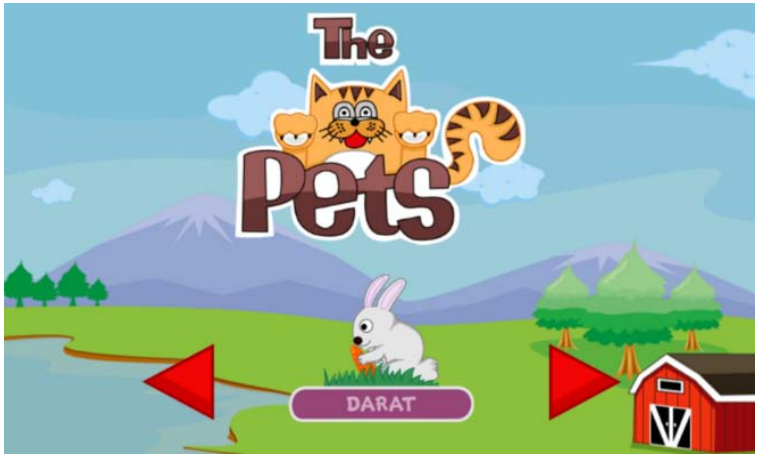

Figure 4.2Display Main Menu

\section{Learning menu}

Figure 4.3 i s a menu of the introduction of pets living on land. There are buttons like back but ton, 1 isten to s ound of a nimals, pet food, a s w ell a s ri ght a nd left but tons t o change s elected animal. There $\mathrm{i} s$ al so a companion $\mathrm{v}$ oice $\mathrm{t}$ hat $\mathrm{t}$ ells $\mathrm{w}$ hether the animal i s be ing viewed, a poppi ng $\mathrm{s}$ ound when animal appears.

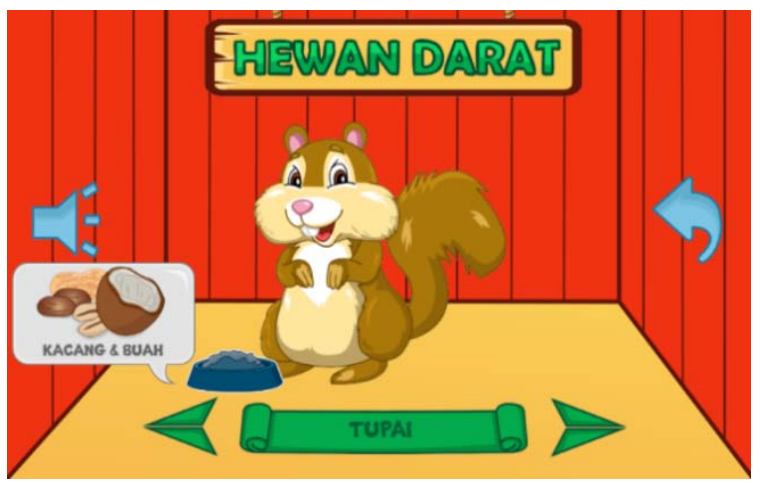

Figure 4.3Display learning menu

\section{Mini game menu}

Figure 4.4 contains $\mathrm{i}$ nteractive $\mathrm{g}$ ames, player is instructed to draw up a pet pictures land in row $s$ of $t$ hree or $m$ ore of $t$ he boxe $s$ that continue to emerge from the bottom up. In every pa rticular po int s peed will be increased and therewill app ear a di fferent animal picture box again.

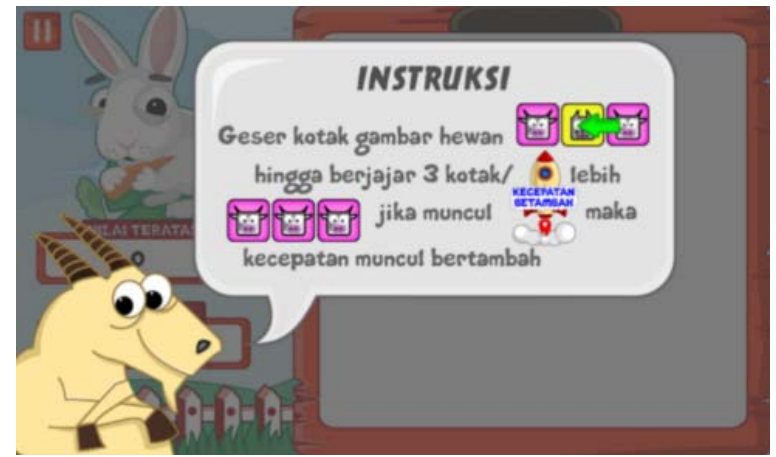

Figure 4.4Display mini game menu

\section{CONCLUSIONS}

From the above di scussion, it can be concluded:

1. "The Pets" is an introduction to the child's game about pets based on food and habitat whichare pr esented into two di fferent 1 anguages, namely Indonesian a nd English. Game "The Pets" for ages 3-6.

2. Graphic "The Pets" i screated by2dimensional i mage $\mathrm{w}$ ith interesting colors s ot hat c hildren are more interested in playing this game. This game ha s a ba se Android platform, and will be upl oaded to Play S tore using the minimum API Level 14 or Android version I ce Cre am Sandwitch.

3. "The Pets" cont ains $t$ hree $\mathrm{m}$ enu: animal habitats. In each menu there is a m enu option to 1 earn and play, every menu booklet tells you how to play the game " The Pets".

\section{ACKNOWLEDGMENT}

Wahyu $\mathrm{F}$ ebriyantois gratefully acknowledged $t \quad$ o BeasiswaUnggulan scholarship s upported from B ereau for Planning a nd I nternational Coope ration, Ministry of E ducation a nd Cul ture of Indonesia.

\section{REFERENCES}

[1] Slamet, "Belajar dan Faktor-Faktor yang Mempengaruhi." $\mathrm{R}$ ineka C ipta, Surabaya, 1991. 
[2] K. Hernawati, "Pengenalan teknologi sejak dini dengan belajar sambil bermain melalui S martphone," i n Seminar Nasional Matematika dan Pendidikan Matematika FMIPA UNY, 2012, no. T 20, pp. 978-979.

[3] J. Freeman a nd U . Munandar, "Cerdas dan Cemerlang." PT. Gramedia Pustaka Utama, Jakarta, 2001.

[4] J. M. M intorogo, A. Adib, a nd A. W . Suhartono, " Perancangan $\mathrm{M}$ edia Interaktif Pengenalan Alphabet Berbasis Alat $\mathrm{P}$ ermainan Eduka tif $\mathrm{U}$ ntuk Anak Usia 2-4 Tahun," J. DKV Adiwarna, vol. 1, no. 4, p. 13, 2014.

[5] A. Budiningsih, "Belajar d an pembelajaran.” $\mathrm{R}$ ineka $\mathrm{C}$ ipta, Jakarta, 2005.

[6] A. Ismail, "Education games m enjadi cerdas da $\mathrm{nc}$ eria de ngan permainan edukatif." P ilar M edia, Y ogyakarta, pp. 155-156, 2006.

[7] M. S. Tedjasaputra, "Bermain, mainan dan pe rmainan." $G$ rasindo, $J$ akarta, 2001.
[8] S. Henry, "Cerdas D engan Game." P T Gramedia Pustaka Utama, Jakarta, 2010.

[9] E. G . Hainstock a nd B . Lumley, "Metode P engajaran Montessori U ntuk Anak P ra-Sekolah.” $P$ ustaka Delapratasa, Jakarta, 1999.

[10] M. Ninawati, "Kajian Dampak Bilingual Terhadap Perkembangan Kognitif Anak Sekolah Dasar," Majalah Ilmiah Widya, Jakarta, pp. 23-24, Oct-2012.

[11]P. G. Dewi Fatma, "Pengembangan Game Edukasi," Yogyakarta, 2012.

[12]M. Bamboo, "Belajar M engenal Binatang." [ Online]. Available: https://play.google.com/store/apps/detail $\mathrm{s}$ ?id=net.bamboomedia.mengenalbinatan g. [Accessed: 03-Jun-2016].

[13]A. Babastudio, " $10 \mathrm{G}$ ame Engine Terbaik S aat I ni," 2014. [O nline]. Available:

http://www.babastudio.com/blog/10game-engine-terbaik-saat-ini.

[Accessed: 14-Jul-2016].

[14] V. W. Febriani and N. A. Wijaya, "High School T echnopreneurship P rogram to Increase $t$ he Educ ational $G$ ames $f$ or Students," Int. J. Comput. Internet Manag., vol. 1, no. SP1, p. 25.1, 2014. 